\title{
Long-term interactions of reduced tillage and different amounts of residue retaining improved soil environment in a semi-arid tropical climate
}

\author{
Shuang Zhong ${ }^{1 *, 2}$ and Hui-cai Zeng ${ }^{3}$ \\ ${ }^{1}$ Chinese Academy of Tropical Agricultural Sciences, Haikou Experimental Station, Haikou 570102, China. \\ *Corresponding author (ongzhish@126.com). \\ ${ }^{2}$ Hainan Key Laboratory of Banana Genetic Improvement, Hainan Haikou 570102, China. \\ ${ }^{3}$ Chinese Academy of Tropical Agricultural Science, Institute of Tropical Bioscience and Biotechnology, Haikou 570101, China.
}

Received: 24 October 2019; Accepted: 1 January 2020; doi:10.4067/S0718-58392020000200197

\begin{abstract}
Soil quality degradation caused by intensification is threatening the sustainability of banana (Musa acuminata Colla) production in South China. Hence comprehensive information about the benefits of conservation management on soil quality is urgently needed. This study aimed to assess the effects of tillage and residue on soil biological properties in a banana plantation for $25 \mathrm{yr}$. Treatments consisted of three tillage methods (conventional tillage, CT; reduced tillage, RT; no tillage, NT) combined with three residue levels (0, NR; 50\%, HR; 100\%, TR). Soil samples were taken in 2018-2019 from $0-40 \mathrm{~cm}$ depth. Soil moisture, $\mathrm{pH}$, total organic $\mathrm{C}$ and total $\mathrm{N}$ in NT were $28.8 \%, 22.4 \%, 39.9 \%$ and $34.3 \%$ higher than in CT. However, NT decreased available P by $16.7 \%$ compared with CT. HR had higher $\mathrm{NH}_{4}-\mathrm{N}$ and available $\mathrm{K}$ and lower bulk density compared with NR. Microbial biomass $\mathrm{C}$ and $\mathrm{N}$ were on average $39.2 \%$ higher in TR than those in NR. Urease, dehydrogenase and $\beta$-glucosidase obtained a mean increase of $34.3 \%$ in RT compared to CT. Invertase and catalase were on average $32.9 \%$ greater when residue was applied than no residue input plots. $\mathrm{CO}_{2}$ and $\mathrm{N}_{2} \mathrm{O}$ emissions decreased around $37.6 \%$ in different tillage treatments, but increased from $39.9 \%$ to $62.6 \%$ in all residue input plots. In general, soil biological properties are sensitive characters to changes caused by tillage and residue, and consequently they are well-established as soil physicochemical indicators for soil quality evaluation in conservation tillage systems.
\end{abstract}

Key words: Biochemical property, gas emission, microbial biomass, residue, tillage.

\section{INTRODUCTION}

The giant, perennial, herbaceous bananas (Musa acuminata Colla) were grown in 51.3 million ha in 2019 with an average production of $69.6 \mathrm{t} \mathrm{ha}^{-1}$ (FAO, IFAD, UNICEF, WFP, and WHO, 2019). The optimum temperature for production is $25^{\circ} \mathrm{C}$. The annual average water requirement is $3500 \mathrm{~mm}$. The period of growth is $280-300 \mathrm{~d}$, usually planted in July of the first year and harvested in May of the second year. Currently, many banana plantations in China have been cropped intensively to satisfy the increased demands for food and fruits. Intensification causes a reduction in soil macroaggregates and microbial abundance which leads to low nutrient availability and accelerated mineralization of soil organic matter. Combining no-tillage with cover crops shows minimal soil disturbance, decreases soil erosion, buffers soil temperature fluctuation and increases microbial activity and community diversity (Melman et al., 2019; Bilgili et al., 2019). The average banana yield in China is $385 \mathrm{t} \mathrm{ha}^{-1}$ at present, which has increased over $260 \%$ in the last decade (Zhang et al., 2018). The main reason is that more than $75 \%$ of the area is devoted to conservation tillage management.

Soil microbiota composition and biochemical parameters are more sensitive than those of physicochemical ones when they are used to analyze changes due to tillage or covering crops. Studies conducted at different climatic regions have 
shown that microflora composition, microbial biomass and enzymes as integrative indicators of soil quality respond to even the slightest modifications in management practices. For instance, reduced tillage greatly increases soil beneficial bacteria abundance and biomass (Saikia et al., 2019). Phosphatases are negatively correlated with P stress and disturbance (Mganga et al., 2016). Soil C and N sequestration respond positively to green manure addition as evidenced by high amount of greenhouse gas emissions (Pareja-Sánchez et al., 2019).

Despite some disadvantages, as represented by the increase of pesticide requirement, conservation tillage has been introduced in arid areas (Sayed et al., 2019) with great success. Conservation tillage is a more sustainable system compared to intensive cropping to solve agro-environmental problems such as soil biodiversity reduction and microbial function decline (Soares et al., 2019). However, most of the previous studies have focused on evaluating the single effects of tillage or crop residue incorporation on soil properties in mono cropping systems at temperate climate with a single timepoint (Yin et al., 2018; Pratibha et al., 2019). Furthermore, the effects of conservation tillage on indicators of soil quality are highly site-specific and therefore cannot be generalized for all agroecological regions with large variability in soil and climatic conditions (Jat et al., 2019). Therefore, the aim of this study was to undertake comprehensive multi-factor studies over 25 growing seasons on the interactive effects of tillage intensity and residue amounts management on soil biological indicators in banana-based rotation systems at semi-arid tropics in silt loam soils. We hypothesized that over a long-term (25 yr) conservation tillage application of reduced tillage combined with the crop residues incorporation in a banana -peanut (Arachis hypogaea L.) rotation has beneficial effects on soil physicochemical and biological properties, compared to conventional tillage (mouldboard plough and residue removal) due to favorable changes in soil environment (such as less disturbance through the reduced tillage and increased soil fertility through the addition of residues).

\section{MATERIALS AND METHODS}

\section{Site description}

The experiment has been conducted at the Ledong Experimental Station (18 37'48.3" N, 108 $47^{\prime} 18.5^{\prime \prime}$ E), Chinese Academy of Tropical Agricultural Sciences, since 1994. Climate of the region is tropical monsoon. Average annual temperature is $25.8{ }^{\circ} \mathrm{C}$ and average annual precipitation is $2065 \mathrm{~mm}$. The test soils are Aquic Hapludepts (13.3\% clay, $23.5 \%$ silt, and $63.2 \%$ sand) according to the USDA texture classification. The soil has $7.22 \mathrm{~g} \mathrm{~kg}^{-1}$ total organic C, 0.73 $\mathrm{g} \mathrm{kg}^{-1}$ total N, $0.61 \mathrm{~g} \mathrm{~kg}^{-1}$ total $\mathrm{P}, 1.23 \mathrm{~g} \mathrm{~kg}^{-1}$, total $\mathrm{K}$ and $\mathrm{pH} 6.59$. The rotation of banana (Musa acuminata Colla) and peanut (Arachis hypogaea L.) was initiated in 1994 for the study (Figure 1).

Figure 1. Study area of a long-term conservation tillage experiment at the Wanzhong Farm in Hainan Island, China.

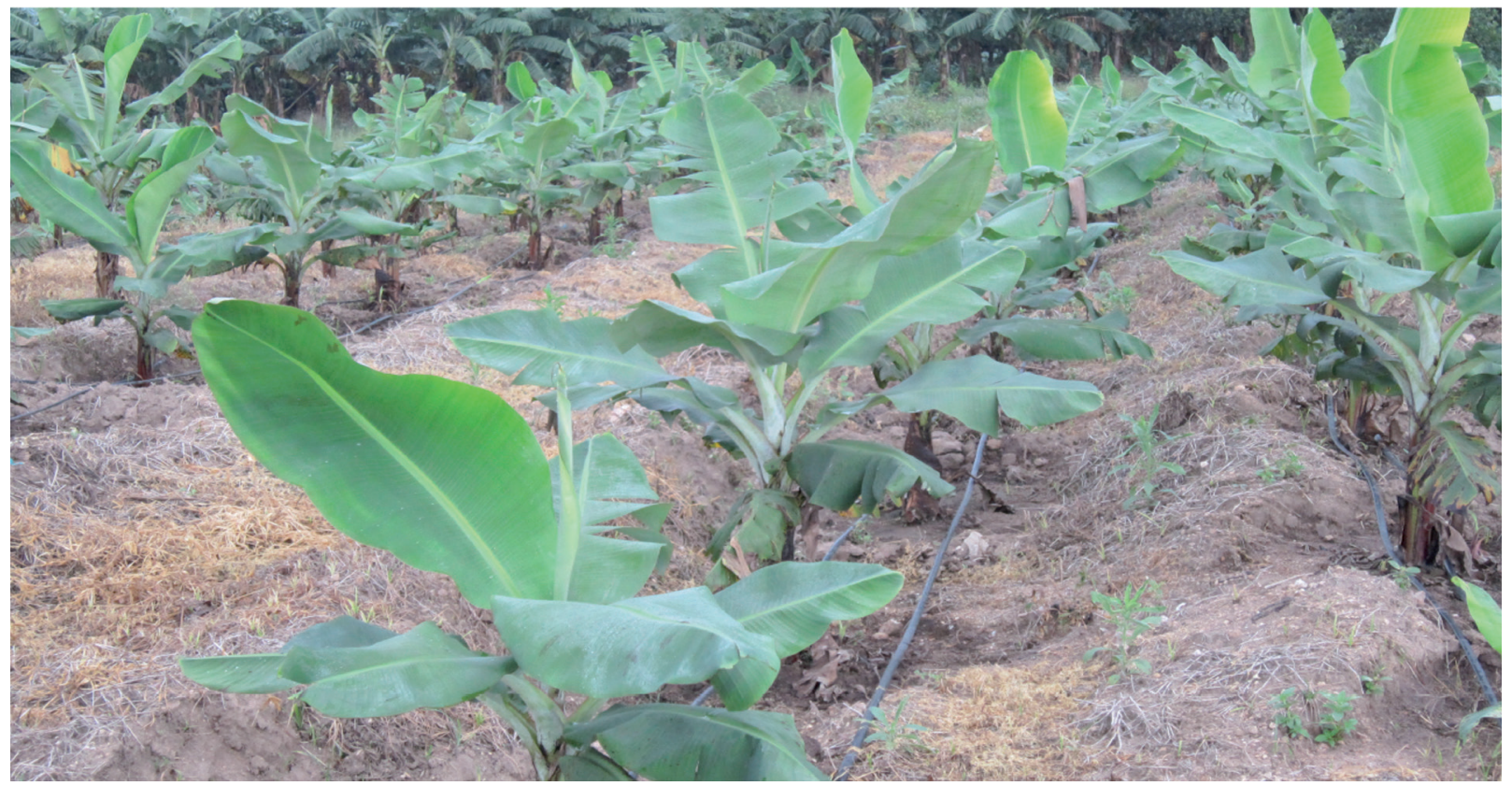


The experiment was a split-plot design with four replicates. Tillage management was the main plot and residue system was the split-plot factor. The text field was divided into nine plots and the size of each plot was $8 \mathrm{~m} \times 7 \mathrm{~m}$. Tillage systems were conventional tillage (CT), reduced tillage (RT) and no-tillage (NT). RT plots were stubble cultivated to $15 \mathrm{~cm}$ depth. CT plots were mouldboard ploughed to $30 \mathrm{~cm}$ depth. Both RT and CT plots were plowed in each May. Banana or peanut residue was incorporated into soil in CT and covered soil surface in RT and NT after harvest. Residue treatments were NR ( 0 , no residues incorporation or coverage), $\mathrm{HR}\left(50 \%, 7.5 \mathrm{tha}^{-1}\right.$ residues incorporation or coverage) and TR $\left(100 \%, 15 \mathrm{t} \mathrm{ha}^{-1}\right.$ residues incorporation or coverage). Each year, cow compost biochar $\left(14.4 \mathrm{t} \mathrm{ha}^{-1}\right)$, with $53.3 \%$ water content, $145 \mathrm{~g} \mathrm{C} \mathrm{kg}^{-1}$, $3.2 \mathrm{~g} \mathrm{~N} \mathrm{~kg}^{-1}, 2.5 \mathrm{~g} \mathrm{P}_{2} \mathrm{O}_{5} \mathrm{~kg}^{-1}, 1.6 \mathrm{~g} \mathrm{~K}_{2} \mathrm{O} \mathrm{kg}^{-1}$, was applied as basal fertilizer. Urea, superphosphate and sulfate were applied as additional fertilizer with the rates of $129 \mathrm{~kg} \mathrm{~N} \mathrm{ha}^{-1}, 68 \mathrm{~kg} \mathrm{P} \mathrm{ha}^{-1}$ and $292 \mathrm{~kg} \mathrm{~K} \mathrm{ha}^{-1}$.

\section{Soil sampling}

Soil samples were taken from 0-40 $\mathrm{cm}$ depth below the soil surface at the seedling stage (16 September 2018), jointing stage (15 December 2018), booting stage (17 March 2019) and ripening stage (19 May 2019) within the rows of plants. Each sample was a composite comprising five random cores $(2.5 \mathrm{~cm}$ diameter). The fresh samples were sieved through a $2 \mathrm{~mm}$ mesh and stored at $4{ }^{\circ} \mathrm{C}$ before subsequent analysis. Results were based on oven-dried weight of the soil.

Soil physicochemical properties were measured according to Hulugalle et al. (2007). Soil microbial biomass was measured by the chloroform fumigation-extraction method (Vance et al., 1987). Urease, acid phosphatase, and dehydrogenase were determined based on the method of Tabatabai (1994). Invertase, $\beta$-glucosidase and catalase were estimated according to the method of Parthasarathi and Ranganathan (2000). For urease, $5 \mathrm{~g}$ soil with $10 \mathrm{~mL}$ of $10 \%$ urea solution were incubated for $24 \mathrm{~h}$ at $\mathrm{pH} 7.0$ at $37^{\circ} \mathrm{C}$; for invertase $5 \mathrm{~g}$ soil with $15 \mathrm{~mL}$ of $8 \%$ sucrose solution were incubated for $24 \mathrm{~h}$ at pH 5.5 at $37{ }^{\circ} \mathrm{C}$; for catalase $2 \mathrm{~g}$ soil with $5 \mathrm{~mL}$ of $0.3 \% \mathrm{H}_{2} \mathrm{O}_{2}$ were incubated for $30 \mathrm{~min}$ at $\mathrm{pH} 7.0$ at $30{ }^{\circ} \mathrm{C}$; for dehydrogenase $6 \mathrm{~g}$ soil with $5 \mathrm{~mL}$ of $3 \%$ triphenyltetrazolium chloride were incubated for $24 \mathrm{~h}$ at $\mathrm{pH} 7.5$ at 37 ${ }^{\circ} \mathrm{C}$; for acid phosphatase $1 \mathrm{~g}$ soil with the $p$-nitrophenyl phosphate substrate were incubated for $1 \mathrm{~h}$ at $\mathrm{pH} 6.5$ at $37^{\circ} \mathrm{C}$; for $\beta$-glucosidase $1 \mathrm{~g}$ soil with the $p$-nitrophenyl- $\beta$-D-glucoside substrate were incubated for $1 \mathrm{~h}$ at $\mathrm{pH} 6.0$ at $37^{\circ} \mathrm{C}$. Enzymes were determined in fresh soil and based on the oven-dried soil weight. Greenhouse gas emissions were measured every $40 \mathrm{~d}$ after crops transplanting, using non-steady state flow-through chambers (Zhang et al., 2014).

\section{Statistical analysis}

Repeated measures ANOVA was used to test the effect of tillage and residue at each sampling stage on soil qualities. Overall effect of tillage, residue and sampling stage on measured variables were analyzed using the linear mixed-effect model procedure for split-plot designs. Differences at $P<0.05$ level were considered significant. When their interactions were significant, individual comparisons were based on an independent-samples $\mathrm{T}$ test. Linear correlation was used to characterize the relationship between physicochemical and biological properties. All statistical analyses were performed by SPSS version 16.0 (IBM, Armonk, New York, USA).

\section{RESULTS}

\section{Soil physicochemical properties}

Significant tillage $(\mathrm{T})$, residue $(\mathrm{R})$ and growth stage $(\mathrm{S})$ effects were observed on the values of bulk density, $\mathrm{pH}$, $\mathrm{NO}_{3}-\mathrm{N}$, and available $\mathrm{K}(P<0.05$, Table 1). Interaction effect of $\mathrm{T} \times \mathrm{R}$ and $\mathrm{T} \times \mathrm{R} \times \mathrm{S}$ was observed in total organic $\mathrm{C}$ and $\mathrm{NH}_{4}-\mathrm{N}(P<0.01)$. Bulk density and $\mathrm{pH}$ were greatly higher at seedling and jointing stages than at booting stage $(P<0.05$, Figures 2 and 3). This was true among all treatments.

Soil moisture and electrical conductivity (EC) were significantly higher in no-tillage (NT) than in conventional tillage (CT) $(P<0.01)$, while available $P$ showed the highest values in conventional tillage $(P<0.05)$. The lowest total organic $\mathrm{C}$ and total $\mathrm{N}$ were found in CTNR, followed by CTHR and RTNR. Exchangeable $\mathrm{Ca}$ and Mg showed the highest values in $100 \%$ residue input plots and the lowest values in residue removal plots. Total $\mathrm{K}$ increased but bulk density decreased after the residue application $(50 \%$ and $100 \%$ residue, $P<0.01)$. 
Table 1. ANOVA for the effects of tillage and residue practices on soil physicochemical and biological properties in a long-term conservation experiment.

\begin{tabular}{lccccccc}
\hline ANOVA & Tillage $(\mathrm{T})$ & Residue $(\mathrm{R})$ & Stage $(\mathrm{S})$ & $\mathrm{T} \times \mathrm{R}$ & $\mathrm{T} \times \mathrm{S}$ & $\mathrm{R} \times \mathrm{S}$ & $\mathrm{T} \times \mathrm{R} \times \mathrm{S}$ \\
\hline $\mathrm{SM}$ & $P$ value & $P$ value & $P$ value & $P$ value & $P$ value & $P$ value & $P$ value \\
$\mathrm{BD}$ & $<0.01$ & $<0.01$ & $\mathrm{~ns}$ & $<0.01$ & 0.037 & $\mathrm{~ns}$ & $\mathrm{~ns}$ \\
$\mathrm{pH}$ & $<0.01$ & 0.031 & $<0.01$ & 0.012 & $\mathrm{~ns}$ & $\mathrm{~ns}$ & $\mathrm{~ns}$ \\
$\mathrm{EC}$ & $<0.01$ & $\mathrm{~ns}$ & $<0.01$ & $<0.01$ & $\mathrm{~ns}$ & $<0.01$ & $\mathrm{~ns}$ \\
$\mathrm{SOC}$ & $<0.01$ & $<0.01$ & $\mathrm{~ns}$ & $<0.01$ & $\mathrm{~ns}$ & $\mathrm{~ns}$ & 0.015 \\
$\mathrm{TN}$ & $<0.01$ & $<0.01$ & $\mathrm{~ns}$ & $<0.01$ & $<0.01$ & $<0.01$ & $<0.01$ \\
$\mathrm{NH}_{4}-\mathrm{N}$ & $<0.01$ & 0.034 & $<0.01$ & $<0.01$ & 0.046 & 0.012 & $<0.01$ \\
$\mathrm{NO}_{3}$-N & $<0.01$ & $<0.01$ & 0.047 & $<0.01$ & $\mathrm{~ns}$ & $<0.01$ & $\mathrm{~ns}$ \\
$\mathrm{AP}$ & $<0.01$ & $<0.01$ & 0.011 & $<0.01$ & $<0.01$ & 0.015 & $\mathrm{~ns}$ \\
$\mathrm{AK}$ & $<0.01$ & 0.011 & $<0.01$ & 0.022 & $<0.01$ & $\mathrm{~ns}$ & $<0.01$ \\
$\mathrm{ECa}$ & $<0.01$ & 0.039 & $<0.01$ & $<0.01$ & $<0.01$ & $<0.01$ & $<0.01$ \\
$\mathrm{EMg}$ & 0.038 & $<0.01$ & $\mathrm{~ns}$ & 0.026 & $\mathrm{~ns}$ & $\mathrm{~ns}$ & $\mathrm{~ns}$ \\
$\mathrm{MBC}$ & $<0.01$ & 0.014 & $<0.01$ & $\mathrm{~ns}$ & $\mathrm{~ns}$ & $\mathrm{~ns}$ & $\mathrm{~ns}$ \\
$\mathrm{MBN}$ & 0.021 & $<0.01$ & $<0.01$ & $\mathrm{~ns}$ & 0.046 & $\mathrm{~ns}$ & $\mathrm{~ns}$ \\
$\mathrm{UA}$ & $<0.01$ & $<0.01$ & 0.044 & $\mathrm{~ns}$ & $\mathrm{~ns}$ & $\mathrm{~ns}$ & 0.024 \\
$\mathrm{IA}$ & $<0.01$ & $<0.01$ & $<0.01$ & 0.023 & $\mathrm{~ns}$ & $\mathrm{~ns}$ & $\mathrm{~ns}$ \\
$\mathrm{DHA}$ & $<0.01$ & $<0.01$ & $<0.01$ & $\mathrm{~ns}$ & $\mathrm{~ns}$ & $<0.01$ & $\mathrm{~ns}$ \\
$\mathrm{APA}$ & 0.043 & 0.022 & $\mathrm{~ns}$ & $\mathrm{~ns}$ & $\mathrm{~ns}$ & $\mathrm{~ns}$ & $<0.01$ \\
$\mathrm{GA}$ & $<0.01$ & $<0.01$ & $<0.01$ & 0.033 & $<0.01$ & $\mathrm{~ns}$ & $\mathrm{~ns}$ \\
$\mathrm{CA}$ & $<0.01$ & 0.019 & $<0.01$ & $\mathrm{~ns}$ & $\mathrm{~ns}$ & 0.035 & $\mathrm{~ns}$ \\
$\mathrm{NE}$ & 0.019 & $<0.01$ & $\mathrm{~ns}$ & 0.031 & $\mathrm{~ns}$ & $\mathrm{~ns}$ & $<0.01$ \\
$\mathrm{CE}$ & $<0.01$ & $<0.01$ & $<0.01$ & $<0.01$ & $\mathrm{~ns}$ & $\mathrm{~ns}$ & $\mathrm{~ns}$ \\
$\mathrm{ME}$ & $<0.01$ & 0.020 & $<0.01$ & $\mathrm{~ns}$ & $\mathrm{~ns}$ & $<0.01$ & $\mathrm{~ns}$ \\
\hline $\mathrm{SM}$ & & & & & & &
\end{tabular}

SM: Soil moisture; BD: bulk density; EC: electrical conductivity; SOC: soil total organic C; TN: total N; AP: available P; AK: available K; ECa: exchangeable Ca; EMg: exchangeable Mg; MBC: microbial biomass C; MBN: microbial biomass N; UA: urease activity; IA: invertase activity; DHA: dehydrogenase activity; APA: acid phosphatase activity; GA: $\beta$-glucosidase activity; $\mathrm{CA}$ : catalase activity; $\mathrm{NE}: \mathrm{N}_{2} \mathrm{O}$ emission; $\mathrm{CE}: \mathrm{CO}_{2}$ emission; $\mathrm{ME}: \mathrm{CH}_{4}$ emission.

\section{Soil microbial biomass and enzymatic activities}

Microbial biomass $\mathrm{C}$, urease, invertase and dehydrogenase were significantly affected by tillage treatments at all sampling stages (Table 1). Microbial biomass N, catalase and $\beta$-glucosidase were significantly affected by residue treatments at three sampling stages (except seedling stage). Interaction of tillage and residue significantly affected microbial biomass $\mathrm{C}$ and dehydrogenase.

Microbial biomass N, urease and acid phosphatase increased by an average of 32.5\% in RT and $44.6 \%$ in NT compared with CT $(P<0.01$, Table 2 and Figure 4$)$. Microbial biomass $C$, dehydrogenase and $\beta$-glucosidase were significantly higher in residue input plots than in the plots without residue $(P<0.05)$. Almost all of the soil enzymes and microbial biomass exhibited temporal fluctuations. A significant increase $(P<0.05)$ appeared during seedling to booting and smoothly decreased afterward.

\section{Soil gaseous emissions}

Tillage effect at all sampling stages, and residue and their interaction at the fifth, sixth and seventh 40-d on $\mathrm{CO}_{2}$ emission was significant $\left(P<0.01\right.$, Table 1). Residue effect on $\mathrm{CH}_{4}$ emission was significant during the growing season. Except the first two $40-\mathrm{d}, \mathrm{N}_{2} \mathrm{O}$ and $\mathrm{CO}_{2}$ emissions were on average $46.5 \%$ lower in less-tilled plots than in conventional tillage (Figure 5). $\mathrm{CO}_{2}$ and $\mathrm{CH}_{4}$ emissions were higher in $100 \%$ residue plots than in $0 \%$ and $50 \%$ residue plots. The average emissions of $\mathrm{CO}_{2}$ and $\mathrm{N}_{2} \mathrm{O}$ were $36.8 \%$ and $40.3 \%$ higher in the booting than in other stages.

Microbial biomass $\mathrm{C}$ was positively correlated with total organic $\mathrm{C}(P<0.01$, Table 3$)$ and negatively with soil moisture $(P<0.05)$. Urease was positively correlated with $\mathrm{NH}_{4}-\mathrm{N}$ and $\mathrm{EC}(P<0.01)$. Acid phosphatase activity was positively correlated with available $\mathrm{P}$ and negatively with $\mathrm{pH}(P<0.05) . \mathrm{CO}_{2}$ emissions were positively correlated with exchangeable $\mathrm{Ca}$, and negatively with bulk density $(P<0.01)$. 
Figure 2. Physicochemical properties in tillage and residue treatments at four sampling stages in a long-term conservation experiment.
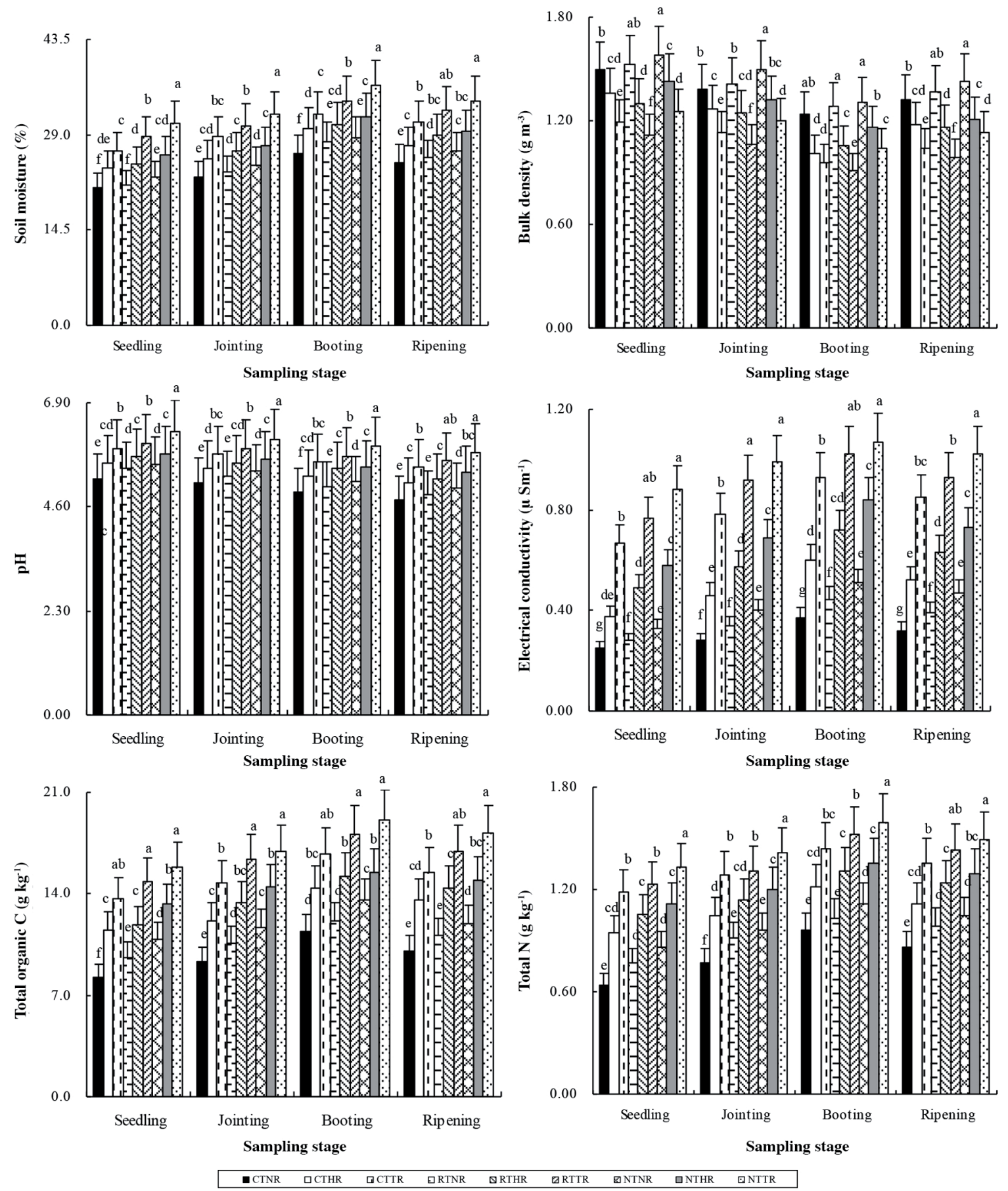

Error bars indicate standard error. Different lower-case letters in the figure mean significant difference according to Duncan's multiple range test $(P<0.05)$.

CT: Conventional tillage; RT: reduced tillage; NT: no-tillage; NR: no residues incorporation; HR: $50 \%$ residues incorporation, $7.5 \mathrm{t} \mathrm{ha}{ }^{-1}$; TR: $100 \%$ residues incorporation, $15 \mathrm{t} \mathrm{ha}^{-1}$. 
Figure 3. Available nutrients in tillage and residue treatments at four sampling stages in a long-term conservation experiment.
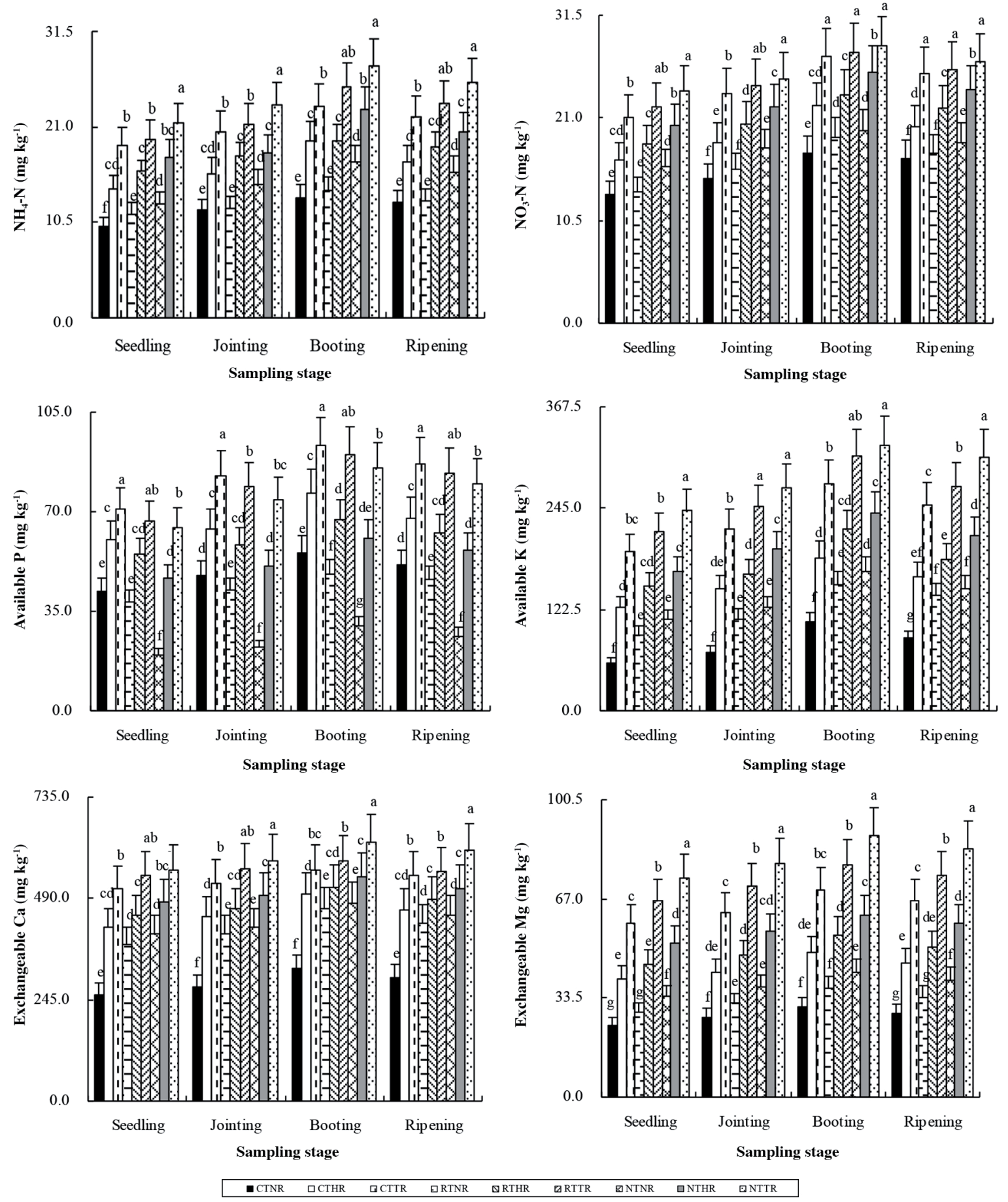

Error bars indicate standard error. Different lower-case letters in the figure mean significant difference according to Duncan's multiple range test $(P<0.05)$.

CT: Conventional tillage; RT: reduced tillage; NT: no-tillage; NR: no residues incorporation; HR: $50 \%$ residues incorporation, $7.5 \mathrm{t} \mathrm{ha}{ }^{-1}$; TR: $100 \%$ residues incorporation, $15 \mathrm{t} \mathrm{ha}^{-1}$. 
Table 2. Soil microbial biomass in tillage and residue treatments at four sampling stages in a long-term conservation experiment.

\begin{tabular}{|c|c|c|c|c|c|c|c|c|c|c|}
\hline \multirow[b]{2}{*}{ Indicators } & \multirow[b]{2}{*}{ Sampling } & \multicolumn{3}{|c|}{$\mathrm{CT}$} & \multicolumn{3}{|c|}{ RT } & \multicolumn{3}{|c|}{ NT } \\
\hline & & NR & HR & TR & NR & HR & TR & NR & HR & TR \\
\hline \multirow{4}{*}{$\begin{array}{l}\text { Microbial } \\
\text { biomass C, } \\
\mathrm{mg} \mathrm{kg}^{-1}\end{array}$} & Seedling & $10.7(1.2) \mathrm{e}$ & $13.6(1.4) \mathrm{cd}$ & $15.1(1.6) \mathrm{c}$ & $11.8(1.3) \mathrm{d}$ & $14.5(1.5) \mathrm{c}$ & $17.6(1.9) \mathrm{b}$ & $16.4(1.8) \mathrm{b}$ & 19.1(2.1)a & $20.0(2.2) \mathrm{a}$ \\
\hline & Jointing & $11.9(1.3) \mathrm{e}$ & 14.1(1.5)d & $16.2(1.7) \mathrm{c}$ & $13.4(1.4) \mathrm{d}$ & $15.8(1.6) \mathrm{c}$ & $18.9(2.1) \mathrm{b}$ & $18.3(2.0) \mathrm{b}$ & $21.2(2.3) \mathrm{a}$ & $22.3(2.4) \mathrm{a}$ \\
\hline & Booting & $14.2(1.5) \mathrm{f}$ & 16.8(1.8)de & $18.6(2.0) \mathrm{d}$ & $15.5(1.7) \mathrm{e}$ & $18.8(2.1) \mathrm{d}$ & $22.7(2.4) \mathrm{bc}$ & $21.9(2.4) \mathrm{c}$ & $24.0(2.5) \mathrm{b}$ & 25.7(2.7)a \\
\hline & Ripening & 13.1(1.4)e & $15.5(1.6) \mathrm{d}$ & $17.8(1.9) \mathrm{c}$ & $14.3(1.5) \mathrm{d}$ & $16.9(1.8) \mathrm{c}$ & 20.8(2.3)ab & $19.5(2.2) \mathrm{b}$ & $22.6(2.4) \mathrm{a}$ & $24.1(2.5) \mathrm{a}$ \\
\hline \multirow{4}{*}{$\begin{array}{l}\text { Microbial } \\
\text { biomass N, } \\
\mathrm{mg} \mathrm{kg}^{-1}\end{array}$} & Seedling & $5.15(0.55) \mathrm{f}$ & $6.96(0.75) \mathrm{e}$ & $8.03(0.86) \mathrm{d}$ & $6.26(0.67) \mathrm{e}$ & $8.43(0.92) \mathrm{d}$ & $9.62(1.03) \mathrm{c}$ & $8.36(0.90) \mathrm{d}$ & $10.5(1.1) \mathrm{b}$ & 12.1(1.3)a \\
\hline & Jointing & $6.41(0.69) \mathrm{e}$ & $7.99(0.86) \mathrm{d}$ & $9.14(0.98) \mathrm{c}$ & $7.42(0.80) \mathrm{d}$ & $9.83(1.06) b c$ & $10.9(1.2) b$ & $9.58(1.02) \mathrm{c}$ & $12.0(1.3) \mathrm{ab}$ & $13.2(1.4) \mathrm{a}$ \\
\hline & Booting & $8.67(0.93) \mathrm{e}$ & $9.64(1.04) \mathrm{d}$ & $11.3(1.2) \mathrm{c}$ & $9.24(0.99) \mathrm{d}$ & $11.9(1.3) \mathrm{c}$ & 13.4(1.4)ab & $12.7(1.4) \mathrm{b}$ & $14.5(1.6) \mathrm{a}$ & $15.8(1.7) \mathrm{a}$ \\
\hline & Ripening & $7.15(0.77) \mathrm{e}$ & $8.21(0.88) \mathrm{d}$ & $10.2(1.1) \mathrm{cd}$ & $8.38(0.91) \mathrm{d}$ & $10.7(1.1) \mathrm{c}$ & $12.1(1.3) \mathrm{b}$ & $11.2(1.2) \mathrm{c}$ & 13.4(1.4)ab & 14.6(1.6)a \\
\hline
\end{tabular}

Values represented in the table as means across replicates of each site. Standard errors are in parentheses.

CT: Conventional tillage; RT: reduced tillage; NT: no-tillage; NR: no residues incorporation; HR: $50 \%$ residues incorporation, $7.5 \mathrm{t} \mathrm{ha}{ }^{-1}$; TR: $100 \%$ residues incorporation, $15 \mathrm{t} \mathrm{ha}^{-1}$.

\section{DISCUSSION}

\section{Effects of tillage on soil quality}

Higher bulk density in NT compared to CT was consistent with Maharjan et al. (2017), and this was attributed to lack of mechanical operations in NT that led to progressive densification. pH increased greatly in RT compared with CT. Kiboi et al. (2019) obtained similar results. They attributed these to basal organic manure addition before transplanting. Total organic $\mathrm{C}$ and $\mathrm{NH}_{4}-\mathrm{N}$ showed the lowest values in $\mathrm{CT}$ and the highest in NT. The results indicate that CT in these lowly fertile soils allows for a faster turnover of soil $\mathrm{C}$ and $\mathrm{N}$ due to disturbed condition (de Cárcer et al., 2019). Reduced tillage greatly increased available K. Similar results were reported by previous researchers (Giagnoni et al., 2019). This is because less-tillage accelerates the accumulation of $\mathrm{K}$-adsorbed particles.

Microbial biomass $\mathrm{C}$ increased by $38.2 \%$ in RT and microbial biomass $\mathrm{N}$ increased by $31.7 \%$ in NT relative to CT, which were consistent with those reported by Vazquez et al. (2019). The positive responses of less tillage to microbial biomass were attributed to larger amount of $\mathrm{C}$ and $\mathrm{N}$ substrates available for microorganisms (Kinoshita et al., 2017), as well as higher soil moisture, total organic $\mathrm{C}$ and total $\mathrm{N}$ compared to $\mathrm{CT}$. In our study, $\mathrm{CO}_{2}$ and $\mathrm{N}_{2} \mathrm{O}$ emissions in RT were on average $29.7 \%$ and $40.1 \%$ lower than in CT, which were attributed to improved soil structures and decreased disturbance in NT. Campanha et al. (2019) found similar negative effects.

Except for catalase, other enzymes generally showed the highest activities in the treatments containing NT. No-tillage brings about two main modifications. Both of them greatly increase soil enzymes. Firstly, residues left on the soil surface help to increase organic C, N and P availability and microbial biomass (Moghimian et al., 2017). Secondly, reduced disturbance caused by NT prevents disruption in microbial community composition (Naujokiene et al., 2019).

\section{Effects of residue on soil quality}

Soil moisture was $32.5 \%$ higher in 50\% residue plots than in plots without residue. The result was in agreement with our previous findings (Zhong and Zeng, 2019) because of the retention on soil surface reducing temperature fluctuation and evaporation. Electrical conductivity increased by $47.8 \%$ for $100 \%$ residue input compared with no residue input. Similar results were reported by Liu et al. (2019). They suggested that accumulation of K, Ca and Mg increased soil salinity. Available $\mathrm{P}$ was unaffected by residue treatments, which showed that $\mathrm{P}$ decomposition of the returned remains would last several years (Nandan et al., 2019). Similar phenomenon had been found by Fang et al. (2018).

Microbial biomass $\mathrm{C}$ and $\mathrm{N}$ were in average $22.6 \%$ higher in 50\% residue input and $38.5 \%$ higher in $100 \%$ residue input than in zero residue input. The reasons may be due to higher nutrient levels and slower $\mathrm{C}$ and $\mathrm{N}$ mineralization in residue input plots compared to residue removal plots (Mangalassery et al., 2019). Urease, invertase and acid phosphatase were strongly increased with the increase of residue returning. This is because $100 \%$ residue input increases microbial biomass and $\mathrm{C}$ storage to the maximum compared with zero $\mathrm{C}$ and $\mathrm{N}$ inputs. Residue treatments increased $\mathrm{CH}_{4}$ emission during July to October, which was consistent with the results of Mei et al. (2018). The possible reasons were that moderate rainfall and large amount of crop stalk coverage provided a better soil environment for methanogens (Huang et al., 2018). 
Figure 4. Soil enzymatic activities in tillage and residue treatments at four sampling stages in a long-term conservation experiment.
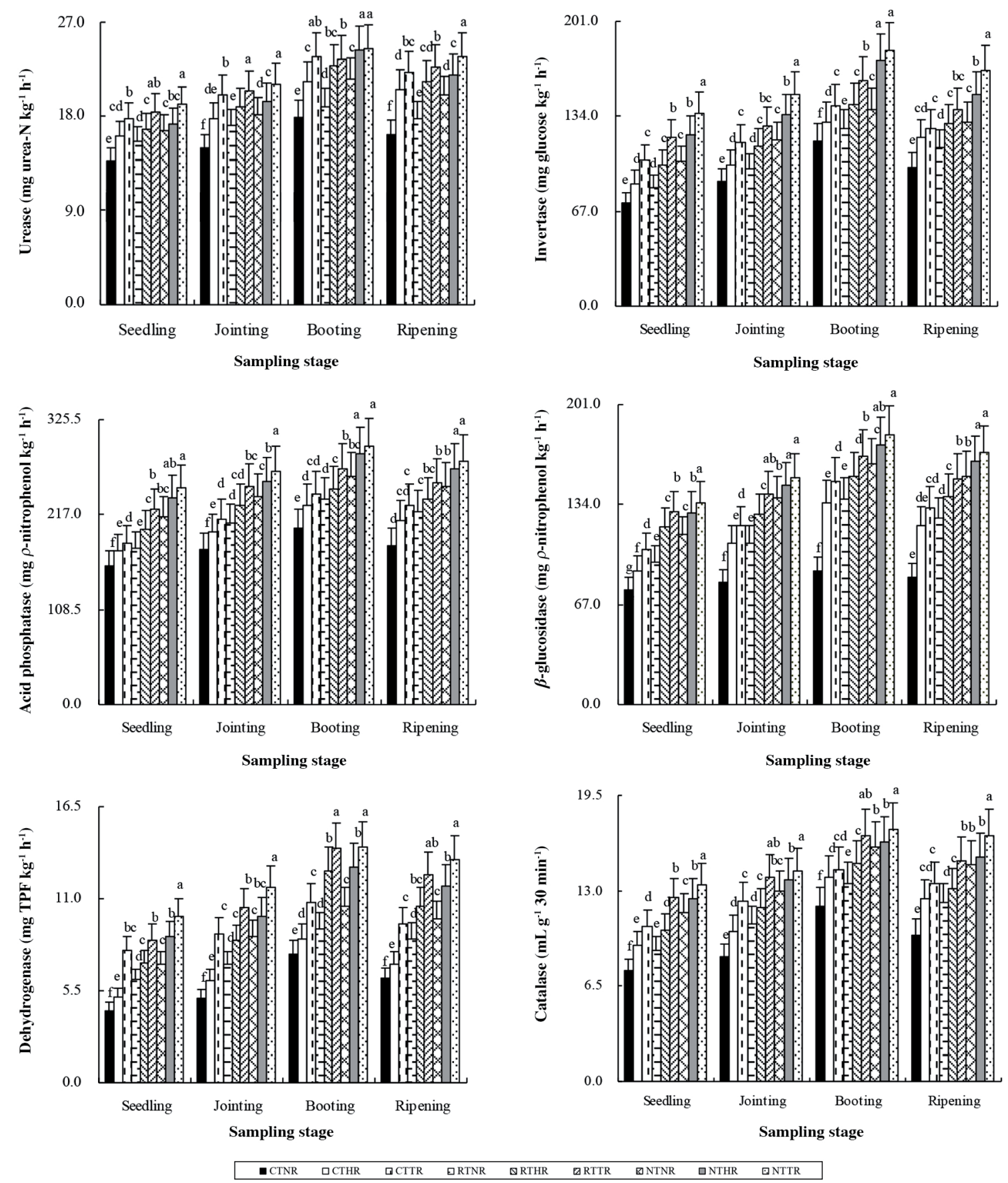

Error bars indicate standard error. Different lower-case letters in the figure mean significant difference according to Duncan's multiple range test $(P<0.05)$.

CT: Conventional tillage; RT: reduced tillage; NT: no-tillage; NR: no residues incorporation; HR: $50 \%$ residues incorporation, $7.5 \mathrm{t} \mathrm{ha}{ }^{-1}$; TR: $100 \%$ residues incorporation, $15 \mathrm{t} \mathrm{ha}^{-1}$; TPF: triphenylformazan. 
Figure 5. Soil gaseous emissions in tillage and residue treatments at four sampling stages in a long-term conservation experiment.
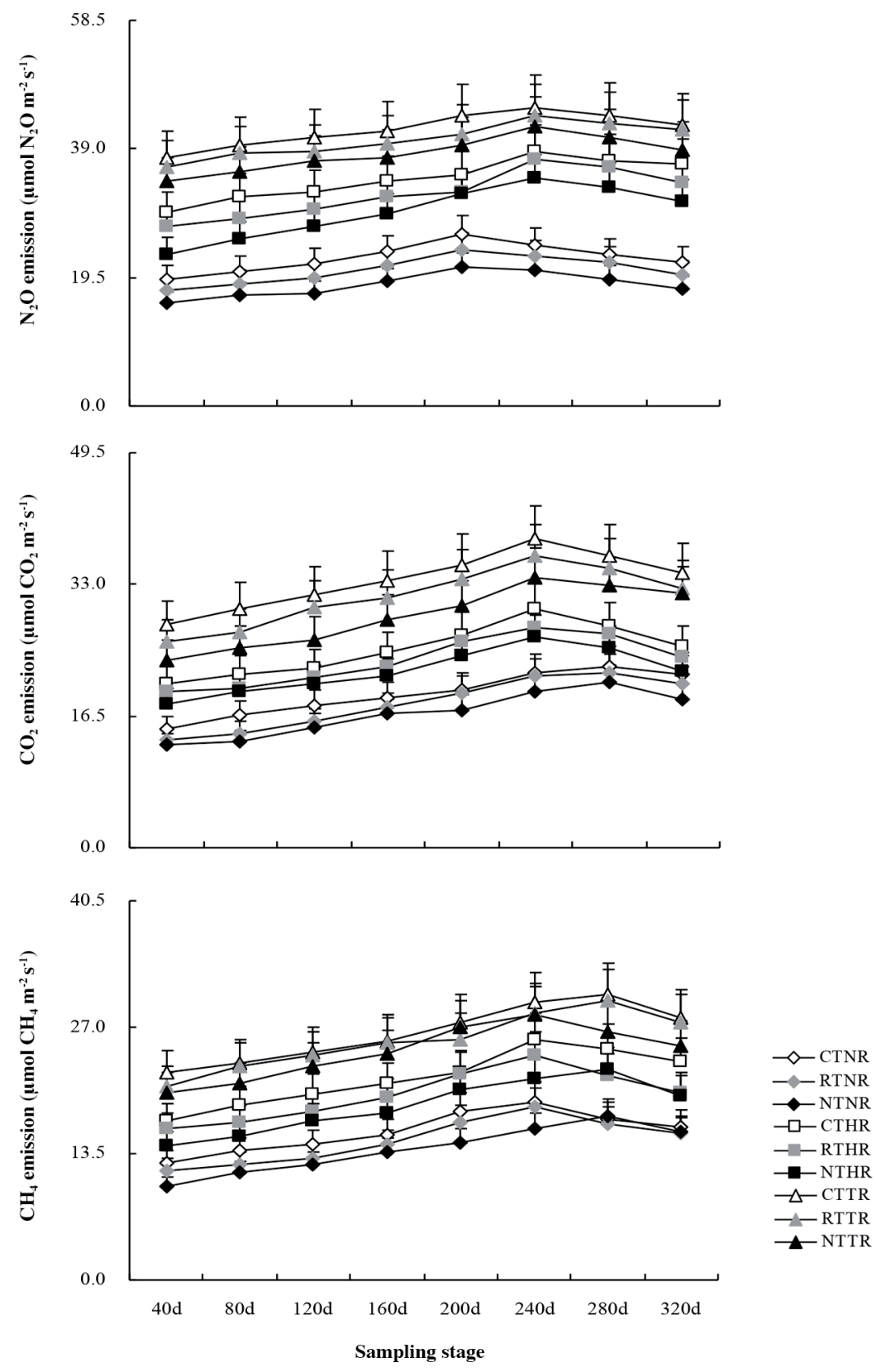

Error bars indicate standard error. Different lower-case letters in the figure mean significant difference according to Duncan's multiple range test $(P<0.05)$.

CT: Conventional tillage; RT: reduced tillage; NT: no-tillage; NR: no residues incorporation; HR: $50 \%$ residues incorporation, $7.5 \mathrm{t} \mathrm{ha}^{-1}$; TR: $100 \%$ residues incorporation, $15 \mathrm{tha}^{-1}$. 
Table 3. Pearson correlation coefficients between soil physicochemical and biological properties across tillage and residue treatments.

\begin{tabular}{|c|c|c|c|c|c|c|c|c|c|c|c|}
\hline Indicators & $\mathrm{MBC}$ & $\mathrm{MBN}$ & UA & IA & GA & APA & DA & CA & $\mathrm{CE}$ & $\mathrm{NE}$ & ME \\
\hline SM & $-0.456^{*}$ & -0.244 & -0.146 & 0.296 & 0.198 & -0.204 & 0.056 & 0.107 & 0.219 & 0.127 & 0.097 \\
\hline $\mathrm{BD}$ & -0.123 & -0.056 & -0.215 & 0.141 & 0.171 & 0.119 & $-0.527 *$ & -0.301 & $-0.588 * *$ & -0.298 & 0.155 \\
\hline $\mathrm{pH}$ & 0.295 & 0.225 & 0.330 & -0.078 & 0.023 & $-0.508 *$ & 0.115 & 0.074 & -0.273 & -0.128 & 0.186 \\
\hline $\mathrm{EC}$ & 0.250 & 0.421 & $0.781 * *$ & -0.316 & -0.368 & $0.695 * *$ & 0.436 & $0.452 *$ & 0.104 & 0.180 & 0.339 \\
\hline SOC & $0.578^{* * *}$ & 0.359 & $0.521^{*}$ & 0.375 & 0.221 & 0.217 & $0.545^{*}$ & 0.305 & $0.509 *$ & -0.009 & 0.177 \\
\hline $\mathrm{TN}$ & 0.289 & $0.611^{* *}$ & $0.512^{*}$ & $0.473 *$ & 0.347 & -0.111 & 0.261 & 0.152 & 0.271 & $0.443^{*}$ & -0.072 \\
\hline $\mathrm{NH}_{4}-\mathrm{N}$ & $0.477 *$ & 0.392 & $0.567 * *$ & 0.324 & 0.103 & 0.225 & $0.609 * *$ & -0.158 & 0.399 & 0.301 & 0.265 \\
\hline $\mathrm{NO}_{3}-\mathrm{N}$ & 0.314 & 0.408 & $0.482^{*}$ & 0.431 & 0.211 & 0.389 & 0.266 & -0.288 & 0.260 & 0.219 & -0.175 \\
\hline $\mathrm{AP}$ & 0.334 & 0.318 & 0.114 & 0.348 & 0.422 & $0.529 *$ & 0.426 & -0.045 & 0.384 & -0.274 & 0.193 \\
\hline AK & 0.224 & 0.205 & 0.194 & $0.587 * *$ & $0.452 *$ & -0.102 & 0.343 & $0.469 *$ & 0.416 & -0.153 & 0.156 \\
\hline $\mathrm{ECa}$ & 0.454 & 0.378 & 0.128 & $0.517 *$ & 0.416 & -0.268 & $0.459 *$ & $0.473 *$ & $0.668 * *$ & 0.138 & -0.186 \\
\hline $\mathrm{EMg}$ & $0.533^{*}$ & $0.679 * *$ & 0.287 & 0.415 & $0.588^{*}$ & -0.407 & 0.346 & 0.314 & 0.446 & 0.243 & -0.050 \\
\hline
\end{tabular}

$*$ ** Significant at the 0.05 and 0.01 probability levels, respectively.

SM: Soil moisture; BD: bulk density; EC: electrical conductivity; SOC: soil organic C; TN: total N; AP: available P; AK: available K; ECa: exchangeable $\mathrm{Ca}$; EMg: exchangeable $\mathrm{Mg}$; MBC: microbial biomass $\mathrm{C}$; MBN: microbial biomass N; UA: urease activity; IA: invertase

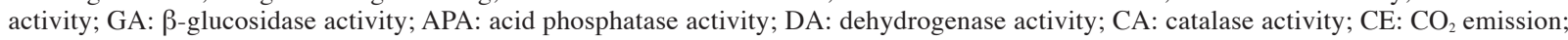
NE: $\mathrm{N}_{2} \mathrm{O}$ emission; $\mathrm{ME}$ : $\mathrm{CH}_{4}$ emission.

Seasonal fluctuations of microbial biomass N, urease and greenhouse gas emission were found among residue systems, being the minimum at seedling, reaching peak at booting then decreasing afterwards. These changes are likely due to crop root growth and soil environment. Over the growing stages, crop roots are vigorous at booting stage (Carlesso et al., 2019), so root exudation rate peaked at the same time. Therefore, preferred substrates are provided for rhizospheric bacteria and fungi. A declined soil temperature and moisture at ripening stage were expected to decrease the emission of $\mathrm{CO}_{2}$ and $\mathrm{N}_{2} \mathrm{O}$ (Volpi et al., 2018).

\section{CONCLUSIONS}

Our results demonstrated that no-tillage combined with maximum amount of residues retaining after $25 \mathrm{yr}$ banana-based rotation significantly increased soil microbial biomass, enzymatic activities and soil $\mathrm{C}$ mineralization. Reduced tillage combined with sufficient residue addition of both crops (banana and peanut) decreased greenhouse gas emissions and increased soil physicochemical properties (soil moisture, $\mathrm{pH}$ and available nutrients). Overall, integration of crop residue application into reduced tillage systems in a semi-arid tropical climate was very effective in reducing soil degradation and maintaining soil fertility. Accordingly, soil biological properties combined with physicochemical parameters should be considered as useful indicators to assess soil quality in conservation tillage practices in sandy loam soils of South China.

\section{ACKNOWLEDGEMENT}

This research was supported by National Natural Science Foundation of China (41301277), Natural Science Foundation of Hainan Province (310073), Central Public-interest Scientific Institution Basal Research Fund for Chinese Academy of Tropical Agricultural Sciences (1630092017005, 1630092017007) and State Scholarships Foundation (201503260016).

\section{REFERENCES}

Bilgili, A.V., Aydemir, S., Altun, O., Saygan, E.P., Yalcin, H., and Schindelbeck, R. 2019. The effects of biochars produced from the residues of locally grown crops on soil quality variables and indexes. Geoderma 345:123-133.

Campanha, M.M., de Oliveira, A.D., Marriel, I.E., Neto, M.M.G., Malaquias, J.V., Landau, E.C., et al. 2019. Effect of soil tillage and $\mathrm{N}$ fertilization on $\mathrm{N}_{2} \mathrm{O}$ mitigation in maize in the Brazilian Cerrado. Science of the Total Environment 692:1165-1174.

Carlesso, L., Beadle, A., Cook, S.M., Evans, J., Hartwell, G., Ritz, K., et al. 2019. Soil compaction effects on litter decomposition in an arable field: Implications for management of crop residues and headlands. Applied Soil Ecology 134:31-37.

de Cárcer, P.S., Sinaj, S., Santonja, M., Fossati, D., and Jeangros, B. 2019. Long-term effects of crop succession, soil tillage and climate on wheat yield and soil properties. Soil and Tillage Research 190:209-219. 
Fang, Y.Y., Singh, B.P., Collins, D., Li, B.Z., Zhu, J., and Tavakkoli, E. 2018. Nutrient supply enhanced wheat residue-carbon mineralization, microbial growth, and microbial carbon-use efficiency when residues were supplied at high rate in contrasting soils. Soil Biology and Biochemistry 126:168-178.

FAO, IFAD, UNICEF, WFP, and WHO. 2019. The state of food security and nutrition in the world 2019. Safeguarding against economic slowdowns and downturns. FAO, Rome, Italy.

Giagnoni, L., Maienza, A., Baronti, S., Vaccari, F.P., Genesio, L., Taiti, C., et al. 2019. Long-term soil biological fertility, volatile organic compounds and chemical properties in a vineyard soil after biochar amendment. Geoderma 344:127-136.

Huang, Y., Ren, W., Wang, L.X., Hui, D.F., Grove, J.H., Yang, X.J., et al. 2018. Greenhouse gas emissions and crop yield in no-tillage systems: A meta-analysis. Agriculture, Ecosystems and Environment 268:144-153.

Hulugalle, N.R., Weaver, T.B., Finlay, L.A., Hare, J., and Entwistle, P.C. 2007. Soil properties and crop yields in a dryland Vertisol sown with cotton-based crop rotations. Soil and Tillage Research 93:356-369.

Jat, H.S., Datta, A., Choudhary, M., Sharma, P.C., Yadav, A.K., Choudhary, V., et al. 2019. Climate Smart Agriculture practices improve soil organic carbon pools, biological properties and crop productivity in cereal-based systems of North-West India. Catena 181:104059.

Kiboi, M.N., Ngetich, K.F., Fliessbach, A., Muriuki, A., and Mugendi, D.N. 2019. Soil fertility inputs and tillage influence on maize crop performance and soil water content in the Central Highlands of Kenya. Agricultural Water Management 217:316-331.

Kinoshita, R., Schindelbeck, R.R., and van Es, H.M. 2017. Quantitative soil profile-scale assessment of the sustainability of long-term maize residue and tillage management. Soil and Tillage Research 174:34-44.

Liu, X., Zhou, F., Hu, G.Q., Shao, S., He, H.B., Zhang, W., et al. 2019. Dynamic contribution of microbial residues to soil organic matter accumulation influenced by maize straw mulching. Geoderma 333:35-42.

Maharjan, M., Sanaullah, M., Razavi, B.S., and Kuzyakov, Y. 2017. Effect of land use and management practices on microbial biomass and enzyme activities in subtropical top-and sub-soils. Applied Soil Ecology 113:22-28.

Mangalassery, S., Kalaivanan, D., and Philip, P.S. 2019. Effect of inorganic fertilisers and organic amendments on soil aggregation and biochemical characteristics in a weathered tropical soil. Soil and Tillage Research 187:144-151.

Mei, K., Wang, Z.F., Huang, H., Zhang, C., Shang, X., Dahlgren, R.A., et al. 2018. Stimulation of $\mathrm{N}_{2} \mathrm{O}$ emission by conservation tillage management in agricultural lands: A meta-analysis. Soil and Tillage Research 182:86-93.

Melman, D.A., Kelly, C., Schneekloth, J., Calderón, F., and Fonte, S.J. 2019. Tillage and residue management drive rapid changes in soil macrofauna communities and soil properties in a semiarid cropping system of Eastern Colorado. Applied Soil Ecology 143:98-106.

Mganga, K.Z., Razavi, B.S., and Kuzyakov, Y. 2016. Land use affects soil biochemical properties in Mt. Kilimanjaro region. Catena 141:22-29.

Moghimian, N., Hosseini, S.M., Kooch, Y., and Darki, B.Z. 2017. Impacts of changes in land use/cover on soil microbial and enzyme activities. Catena 157:407-414.

Nandan, R., Singh, V., Singh, S.S., Kumar, V., Hazra, K.K., Nath, C.P., et al. 2019. Impact of conservation tillage in rice-based cropping systems on soil aggregation, carbon pools and nutrients. Geoderma 340:104-114.

Naujokiene, V., Sarauskis, E., Bleizgys, R., and Sasnauskiene, J. 2019. Soil biotreatment effectiveness for reducing global warming potential from main polluting tillage operations in life cycle assessment phase. Science of the Total Environment 671:805-817.

Pareja-Sánchez, E., Cantero-Martínez, C., Álvaro-Fuentes, J., and Plaza-Bonilla, D. 2019. Tillage and nitrogen fertilization in irrigated maize: key practices to reduce soil $\mathrm{CO}_{2}$ and $\mathrm{CH}_{4}$ emissions. Soil and Tillage Research 191:29-36.

Parthasarathi, K., and Ranganathan, L.S. 2000. Aging effect on enzyme activities in pressmud vermicasts of Lampito mauritii (Kinberg) and Eudrilus eugeniae (Kinberg). Biology and Fertility of Soils 30:347-350.

Pratibha, G., Srinivas, I., Rao, K., Raju, M.K., Shanker, A.K., Anamika, J., et al. 2019. Identification of environment friendly tillage implement as a strategy for energy efficiency and mitigation of climate change in semiarid rainfed agro ecosystems. Journal of Cleaner Production 214:524-535.

Saikia, S., Sharma, R., Thind, H.S., Sidhu, H.S., and Singh, Y. 2019. Temporal changes in biochemical indicators of soil quality in response to tillage, crop residue and green manure management in a rice-wheat system. Ecological Indicators 103:383-394.

Sayed, A., Sarker, A., Kim, J.E., Rahman, M., and Mahmud, G.A. 2019. Environmental sustainability and water productivity on conservation tillage of irrigated maize in red brown terrace soil of Bangladesh. Journal of the Saudi Society of Agricultural Sciences. In Press. Available online 26 March. https://doi.org/10.1016/j.jssas.2019.03.002.

Soares, D.S., Ramos, M.L.G., Marchao, R.L., Maciel, G.A., and de Carvalho, A.M. 2019. How diversity of crop residues in long-term no-tillage systems affect chemical and microbiological soil properties. Soil and Tillage Research 194:104316.

Tabatabai, A. 1994. Soil enzymes. p. 775-833. In Weaver, R.W., Angle, J.S., and Bottomley, P.S. (eds.) Methods of soil analysis. Part 2. Microbiological and biological properties. $2^{\text {nd }}$ ed. Soil Science Society of America, Madison, Wisconsin, USA.

Vance, E.D., Brookes, P.C., and Jenkinson, D.S. 1987. An extraction method for measuring microbial biomass C. Soil Biology and Biochemistry 19:703-707. 
Vázquez, E., Benito, M., Espejo, R., and Teutscherova, N. 2019. Effects of no-tillage and liming amendment combination on soil carbon and nitrogen mineralization. European Journal of Soil Biology 93:103090.

Volpi, I., Antichi, D., Ambus, P.L., Bonari, E., Nasso, N.N., and Bosco, S. 2018. Minimum tillage mitigated soil $\mathrm{N}_{2} \mathrm{O}$ emissions and maximized crop yield in faba bean in a Mediterranean environment. Soil and Tillage Research 178:11-21.

Yin, T., Zhao, C.X., Yan, C.R., Du, Z.L., and He, W.Q. 2018. Inter-annual changes in the aggregate-size distribution and associated carbon of soil and their effects on the straw-derived carbon incorporation under long-term no-tillage. Journal of Integrative Agriculture 17:2546-2557.

Zhang, Y., Li, Z.J., Feng, J.F., Zhang, X., Jiang, Y., Chen, J., et al. 2014. Differences in $\mathrm{CH}_{4}$ and $\mathrm{N}_{2} \mathrm{O}$ emissions between rice nurseries in Chinese major rice cropping areas. Atmospheric Environment 96:220-228.

Zhang, Y., Li, X.J., Gregorich, E.G., McLaughlin, N.B., Zhang, X.P., Guo, Y.F., et al. 2018. No-tillage with continuous maize cropping enhances soil aggregation and organic carbon storage in Northeast China. Geoderma 330:204-211.

Zhong, S., and Zeng, H.C. 2019. Influence of long-term tillage and residue management on soil biota in tropical climate. Journal of Biobased Materials and Bioenergy 13:576-584. 